\title{
Assessing the Potential of Mangrove Educotourism to Marine Protected Area: A Case of Tioman and Tulai Islands, Pahang, Malaysia
}

\author{
Shahbudin Saad1,2*, Zuhairi Ahmad', Mohd Husaini Rani1, Mohd Fikri Akmal Khodzori', \\ Muhammaad Hamizan Yusof1, Normawaty Mohammad Noor1,2, Yukinori Mukai1,2 \\ ${ }^{1}$ Department of Marine Science, Kulliyyah of Science, International Islamic University Malaysia, Jalan Sultan \\ Ahmad Shah, Bandar Indera Mahkota, Kuantan, Malaysia \\ ${ }^{2}$ Research fellow for Institute of Oceanography and Maritime Studies, International Islamic University Malaysia, \\ Jalan Sultan Ahmad Shah, Bandar Indera Mahkota, Kuantan, Malaysia \\ Email: ${ }^{*}$ ocean@iium.edu.my, ${ }^{*}$ Shahbudin277@yahoo.com
}

Received 22 November 2015; accepted 17 July 2015; published 20 July 2015

Copyright (C) 2015 by authors and Scientific Research Publishing Inc.

This work is licensed under the Creative Commons Attribution International License (CC BY). http://creativecommons.org/licenses/by/4.0/

\section{Open Access}

\begin{abstract}
Mangroves composition and species are richly diverse in Tioman and Tulai Island. A total of 23 mangrove species have been found consisting of exclusive and non-exclusive species in Kg. Juara, Kg. Nipah, Kg. Paya, Kg. Genting and Tulai Island. The abundance mangrove species are Rhizophora $X$ lamarckii, Rhizophora apiculata, Rhizophora mucronata and Brugueira gymnorrhiza. From supervised classification, total of $\mathbf{5 9 . 9 0}$ hectares mangrove covers have been identified in both islands, with $86.49 \%$ in Tioman Island (52.76 hectares) and $13.51 \%$ in Tulai Island (7.14 hectares). A new hybrid species has been found (Rhizophora $X$ lamarckii) dominated in Tulai Island, combination between Rhizophora stylosa and Rhizophora apiculata. At the mean time only mangrove area in Teluk Bakau, Tulai Island is considered as the focal destination of tourists to the area. However, other mangrove areas in Tioman Island are also potential to be promoted as tourist destination areas. Although the mangrove area is only a part of the scenery, its presence obviously enhances tourist attraction. The basic facilities such as information counter, walking trails, garbage boxes and toilets are considered necessary. The main information panel and site map should be provided on the mangrove sites. Boardwalks may be constructed for visitor to access the mangrove area without destroying the root system and stand. The actual site of these facilities and on-site information guides should be strategically placed in order to provide beneficial information and as well as to sustain the biophysical stability of the sites. Since mangroves provide vari-
\end{abstract}

"Corresponding author.

How to cite this paper: Saad, S., Ahmad, Z., Rani, M.H., Khodzori, M.F.A., Yusof, M.H., Noor, N.M. and Mukai, Y. (2015) Assessing the Potential of Mangrove Educotourism to Marine Protected Area: A Case of Tioman and Tulai Islands, Pahang, Malaysia. Natural Resources, 6, 442-449. http://dx.doi.org/10.4236/nr.2015.67042 
ous important functions in nature, it hopes that the mangrove educotourism activity will influence the people and community's attitudes to the environment, conservation and sustainable development in a very positive way.

\section{Keywords}

\section{Mangrove Classification, Educotourism, Diversity and Distribution, Hybrid Species}

\section{Introduction}

Mangroves are coastal trees that occupy the intertidal zone in estuaries, lagoons, and coastal mudflats in tropical and subtropical areas. Mangrove is one of the most productive ecosystems which directly or indirectly provide valuable natural ecological functions and socioeconomic values to men and environment [1]. They play important roles in buffer zone, coastal stabilization, habitat and nursery grounds, wildlife reserves, human habitation and aquaculture. Despite of their importance, the mangrove ecosystem is threatened with destruction through various forms of human pressure [2]-[4]. Tioman, one of the main tourism islands in Malaysia has a plenty of mangrove species that become a key to its healthy marine ecology. The health and extend of coral reefs in Tioman are largely dependent on coastal mangrove forest. These two marine ecosystems have a symbiotic relationship and a mutual function in forming the barrier that protects shorelines from the destructive forces of wind and waves especially during the northeast monsoon. However, the pace of coastal development especially on the west coast of Tioman had suppressed the mangroves propagation over the years. In order to sustain the natural resources and maintain the ecosystem health, it is essential to preserve, conserve and properly manage the mangroves in the islands. Public awareness on the importance and value of mangroves has been identified as a critical factor in the conservation and restoration of this ecosystem. The assumption of mangroves as wasteland by many people could be transformed into a very important marine ecosystem by introducing a concept of educotourism. The mangroves could be developed as research facilities and as well as observation and education facilities. Through careful planning, educotourism can provide a lot of benefit to the environment and at the same time, generate income to local stakeholders and the agencies responsible for the mangrove management.

\section{Materials and Methods}

\subsection{Study Area}

Tioman Island, located in the east coast of peninsular Malaysia (Figure 1) is gazetted under Marine Park Department supervision. The island (N2 $42^{\prime} 49.56^{\prime \prime}$ in latitudes and E104 $00^{\circ} 37.46$ " in longitudes) faced bimodal patterns of two monsoon periods; Northeast Monsoon from October to March and Southwest Monsoon from June to September [5] [6]. It was chosen as a case study in this research because it is a popular ecotourism destination due to its beautiful shore, diversity of its coral, and pristine mangrove. Generally, the mangrove forests were observed behind most estuaries especially in southern and western part of the island. Besides that, the mangrove forests were also observed at the bay such as in Teluk Bakau, Tulai Island. The composition and species was richly diverse in both Tioman and Tulai Island. Due to that reason, Tioman and Tulai Island have a potential to be promoted as ecotourism destination and attract numbers of visitors to the mangrove forest.

\subsection{Image Processing and Ground Truthing}

Landsat-7 ETM+ SLC off (Path: 125, Row: 58; Date: 16/6/2012) have been pre-processed according to standard methods of image classification [7]-[9] to produce supervised image of mangrove mapping (Figure 2). The ground truth data have been applied to these procedures in order to provide better classification and accuracies. By using Global Positioning System (GPS), a total of 46 sampling points were selected to identify as sampling stations for collecting signatures information. The signatures were used to find exact error between true coordinates on the ground and the marked coordinates during supervised classification [7]. Most dominant species and tree density on each station were estimated and recorded. Composition of mangrove species was estimated 


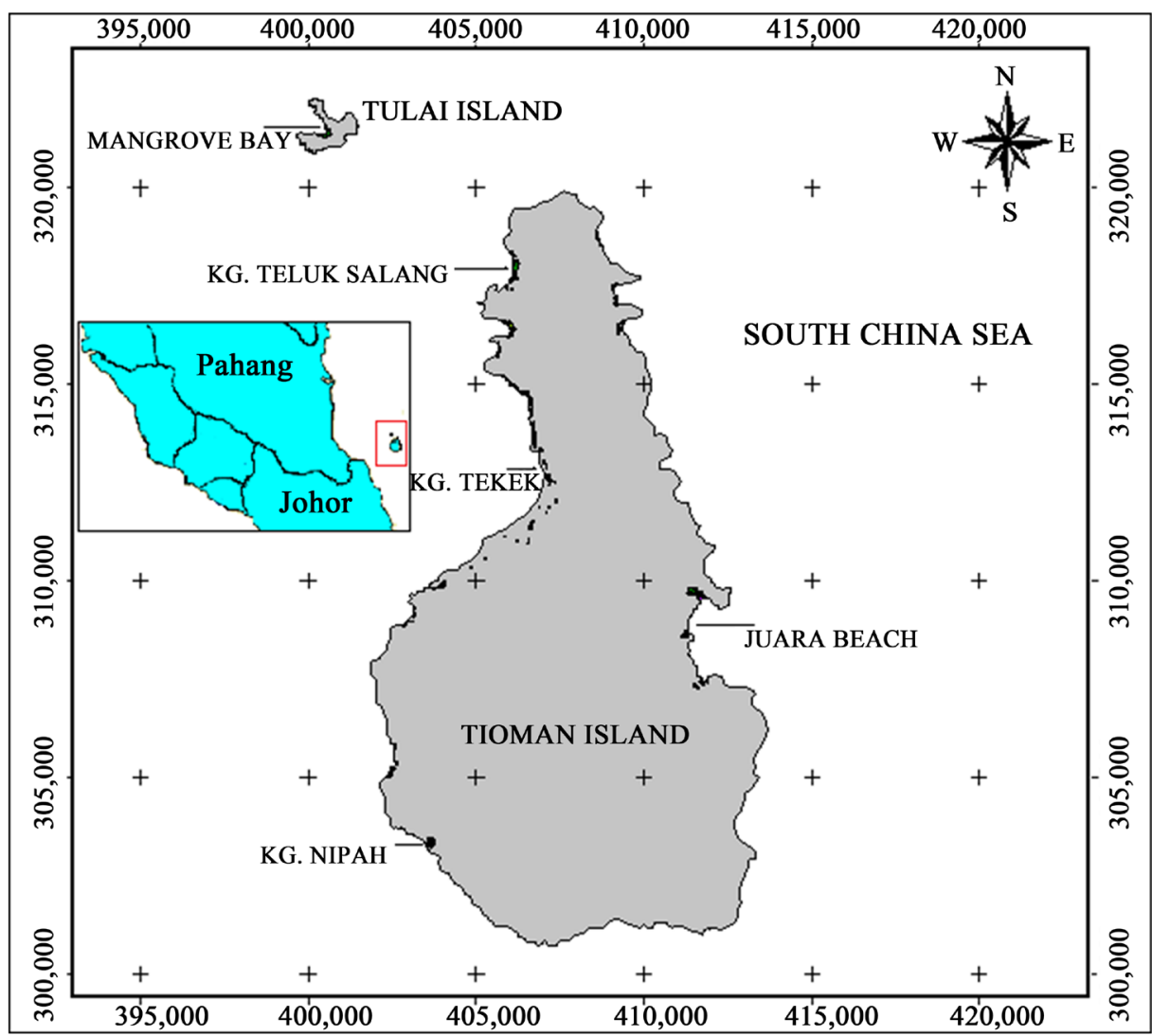

Figure 1. The map showed the locations of study area.

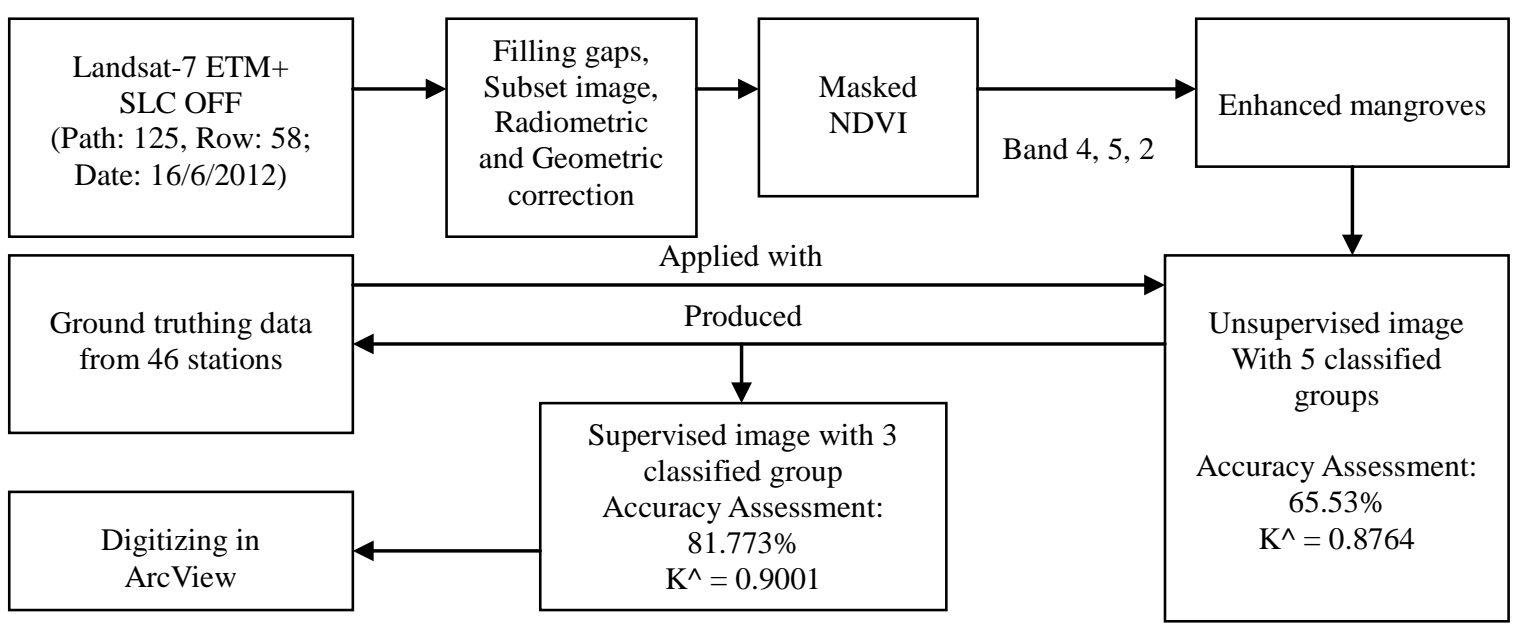

Figure 2. Flow chart of standard image processing and mapping [9].

visually [7] [10]. The classification of each mangrove tree species was based on following criteria; roots, bark, fruits, flowers, propagules, and leaf. Separability analysis and accuracy analysis have been conducted in order to evaluate reliabilities and validities of mapping. The Kappa coefficient expresses the proportionate reduction in error generated by a classification process compared with the error of a completely random classification. Based on unsupervised classification, 5 random class of computer generated have been produced. From PCA analysis, the spectral from these 5 classes found to be overlapped with each other based on spectral similarities. Thus, class grouping and merging have been conducted using species identification data from field sampling. 


\section{Results and Discussion}

\subsection{Mangrove Diversity}

Twenty-three (23) mangrove species were found at 46 sampling stations across the Tioman and Tulai Island throughout ground trothing (Table 1). Sixteen (16) of these identified mangrove species were categorized as exclusive species and seven (7) as non-exclusive [11] [12] (Table 2). A new hybrid species (Rhizophora X lamarkii) has been found dominated in Tulai Island. It is combination between Rhizophora apiculata and Rhizophora stylosa.

\subsection{Mangrove Classification and Mapping}

Supervised classifications have been conducted using merged signatures from overlapping spectral properties into 3 major classification groups (Mangrove A, Mangrove B and Mangrove C) (Table 3). From supervised classification, total of 59.90 hectares mangrove covers have been identified in both islands, with $86.49 \%$ in Tioman Island (52.76 hectares) and 13.51\% in Tulai Island (7.14 hectares) (Table 4). In Tioman Island (Figure 3), Mangrove A covers 59.91\% (31.61 hectares) of total mangrove in the island, and Mangrove B and Mangrove C with 13.64\% (7.2 hectares) and 26.43\% (13.95 hectares). In Tulai Island (Figure 3), only Mangrove A and Mangrove B were observed. Mangrove A occupies 85.48\% (6.0975 hectares) and Mangrove B covers 14.51\% (1.035 hectares) of total mangroves area in the island. The summarized result of mangrove cover is shown in Table 3.

\subsection{The Potential of Mangroves for New Educotourism Developments in Tioman Island}

Tulai is a small island located at northwest coast of Tioman. It is also often referred to as Coral Island or Mangrove Bay by tourist boat operators that offer daily excursion to this island. Interesting about Tulai Island is about their coral and mangroves. The symbiotic relationship between coral and mangrove is clearly seen with crystal

Table 1. List of mangrove species found in tioman island (Kg. Genting, Kg. Paya, Kg. Nipah, Kg. Tekek and Kg. Juara) and Tulai Island (Tlk. Bakau).

\begin{tabular}{|c|c|c|c|c|c|c|c|}
\hline No & Species & Genting & Paya & Nipah & Tekek & Juara & Tulai \\
\hline 1 & Avicennia alba & & & $\sqrt{ }$ & $\sqrt{ }$ & $\sqrt{ }$ & \\
\hline 2 & Lumnitzera racemosa & & & & & $\sqrt{ }$ & \\
\hline 3 & Terminalia cattappa & & & & $\sqrt{ }$ & $\sqrt{ }$ & \\
\hline 4 & Milletia pinnate & & $\sqrt{ }$ & & & $\sqrt{ }$ & \\
\hline 5 & Aganope heptaphylla & & & & $\sqrt{ }$ & $\sqrt{ }$ & $\sqrt{ }$ \\
\hline 6 & Hibiscus tiliaceus & & & & & $\sqrt{ }$ & \\
\hline 7 & Thespesia populnae & & $\sqrt{ }$ & & & & \\
\hline 8 & Xylocarpus granatum & & $\sqrt{ }$ & & & $\sqrt{ }$ & \\
\hline 9 & Aegiceras corniculatum & & & $\sqrt{ }$ & & & \\
\hline 10 & Nypa frutican & $\sqrt{ }$ & $\sqrt{ }$ & $\sqrt{ }$ & $\sqrt{ }$ & $\sqrt{ }$ & \\
\hline 11 & Oncosperma tigillarium & $\sqrt{ }$ & & $\sqrt{ }$ & & & \\
\hline 12 & Acrostichum aureum & $\sqrt{ }$ & & & & $\sqrt{ }$ & \\
\hline 13 & Rhizophora apiculata & & & & & & $\sqrt{ }$ \\
\hline 14 & Rhizophora mucronata & $\sqrt{ }$ & $\sqrt{ }$ & & & $\sqrt{ }$ & \\
\hline 15 & Rhizophora stylosa & & & & & & $\sqrt{ }$ \\
\hline 16 & Rhizophora X lamarckii & & & & & & $\sqrt{ }$ \\
\hline 17 & Brugueira cylindrica & & & & & $\sqrt{ }$ & \\
\hline 18 & Bruguiera gymnorrhiza & & $\sqrt{ }$ & $\sqrt{ }$ & & $\sqrt{ }$ & $\sqrt{ }$ \\
\hline 19 & Bruguiera sexangular & & & & & $\sqrt{ }$ & $\sqrt{ }$ \\
\hline 20 & Ceriops sp. & & & & & $\sqrt{ }$ & \\
\hline 21 & Sonneratia alba & & $\sqrt{ }$ & $\sqrt{ }$ & $\sqrt{ }$ & $\sqrt{ }$ & $\sqrt{ }$ \\
\hline 22 & Sonneratia ovata & & & & & $\sqrt{ }$ & \\
\hline 23 & Heritiera globosa & $\sqrt{ }$ & & & & $\sqrt{ }$ & \\
\hline
\end{tabular}


Table 2. Classification of mangroves based on species local names, exclusive and non-exclusive in the study area.

\begin{tabular}{|c|c|c|c|c|c|}
\hline No & Family & Species & Malay name & Life-form & Type $^{*}$ \\
\hline 1 & Avicenniaceae & Avicennia sp. & Api-api & Tree & E \\
\hline \multirow{2}{*}{2} & \multirow{2}{*}{ Combretaceae } & Lumnitzera racemosa & Teruntum Putih & Shrub/Tree & $\mathrm{E}$ \\
\hline & & Terminalia cattappa & Ketapang & Tree & NE \\
\hline \multirow{2}{*}{3} & \multirow{2}{*}{ Leguminosae } & Milletia pinnate & Marabahai & Tree & NE \\
\hline & & Aganope heptaphylla & Tali berkumpul & Tree & $\mathrm{NE}$ \\
\hline \multirow{2}{*}{4} & \multirow{2}{*}{ Malvaceae } & Hibiscus tiliaceus & Bebaru & Tree & $\mathrm{NE}$ \\
\hline & & Thespesia populnae & Baru & Tree & $\mathrm{NE}$ \\
\hline 5 & Meliaceae & Xylocarpus granatum & Nyireh Bunga & Tree & $\mathrm{E}$ \\
\hline 6 & Myrsinaceae & Aegiceras sp. & Kacang-kacang & Shrub & E \\
\hline \multirow{2}{*}{7} & \multirow{2}{*}{ Palmae } & Nypa frutican & Nipah & Palm & $\mathrm{E}$ \\
\hline & & Oncosperma tigillarium & Nibung & Palm & $\mathrm{NE}$ \\
\hline \multirow[t]{4}{*}{8} & Pteridaceae & Acrostichum aureum & Piai Raya & Fern & $\mathrm{NE}$ \\
\hline & \multirow{8}{*}{ Rhizophoraceae } & Rhizophora apiculata & Bakau Minyak & Tree & E \\
\hline & & Rhizophora mucronata & Bakau Kurap & Tree & E \\
\hline & & Rhizophora stylosa & Bakau Pasir & Tree & E \\
\hline \multirow{5}{*}{9} & & Rhizophora X lamarckii & - & Tree & E \\
\hline & & Brugueira cylindrica & Berus & Tree & E \\
\hline & & Bruguiera gymnorrhiza & Tumu Merah & Tree & E \\
\hline & & Bruguiera sexangular & Tumu & Tree & E \\
\hline & & Ceriops sp. & Tengal/Tengah & Tree & E \\
\hline \multirow{2}{*}{10} & \multirow{2}{*}{ Sonneratiaceae } & Sonneratia alba & Pedada & Tree & E \\
\hline & & Sonneratia ovata & Perepat & Tree & E \\
\hline 11 & Sterculiaceae & Heritiera globosa & Dungun Besar & Tree & E \\
\hline
\end{tabular}

${ }^{*} \mathrm{E}=$ Exclusive species, NE = Non-exclusive species, source: [11] [12].

Table 3. Classification groups by mangrove species spectral similarities. Note that the mangrove species in gray columns shared similar spectral which overlapped during unsupervised classification.

\begin{tabular}{|c|c|c|}
\hline Class & & \\
\hline \multirow{6}{*}{ Mangrove A } & Rhizophora X lamarckii & Rhizophora mucronata \\
\hline & Brugueira gymnorrhiza & Brugueira cylindrica \\
\hline & Bruguiera sexangular & Sonneratia alba \\
\hline & & Sonneratia ovata \\
\hline & & Xylocarpus granatum \\
\hline & & Terminalia cattappa \\
\hline \multirow{4}{*}{ Mangrove B } & Rhizophora apiculata & Rhizophora stylosa \\
\hline & Brugueira gymnorrhiza & Hibiscus tiliaceus \\
\hline & Bruguiera sexangular & Ceriops decandra \\
\hline & & Lumnitzera racemosa \\
\hline \multirow{3}{*}{ Mangrove C } & Rhizophora apiculata & Avicennia sp. \\
\hline & & Nypa frutican \\
\hline & & Aegiceras sp. \\
\hline
\end{tabular}

Table 4. Mangrove covers in Tioman and Tulai Island.

\begin{tabular}{cccc}
\hline Mangrove Class & Tulai Island & Tioman Island & Total Area (hectares) \\
\hline Mangrove A & 6.10 & 31.61 & $\mathbf{3 7 . 7 1}$ \\
Mangrove B & 1.04 & 7.20 & $\mathbf{8 . 2 4}$ \\
Mangrove C & - & 13.95 & $\mathbf{1 3 . 9 5}$ \\
Total area (hectares) & $\mathbf{7 . 1 4}$ & $\mathbf{5 2 . 7 6}$ & $\mathbf{5 9 . 9 0}$ \\
\hline
\end{tabular}



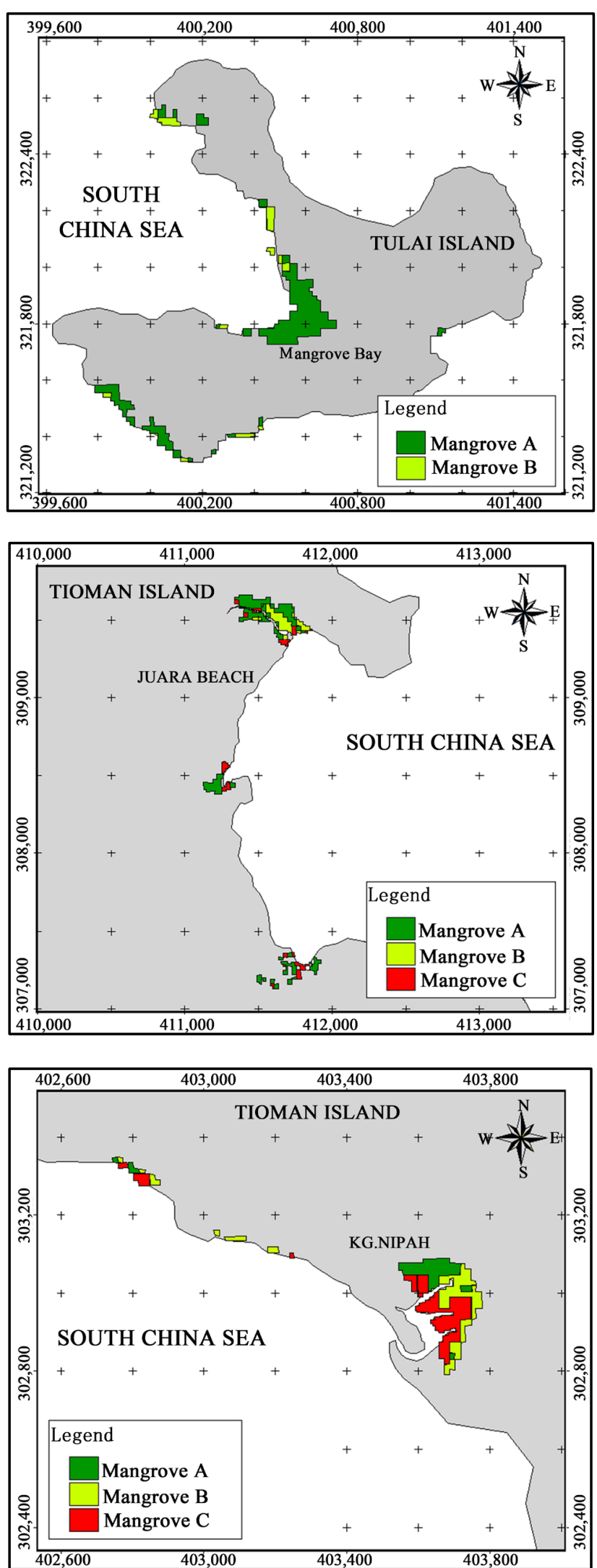

Figure 3. Mangrove distribution in Tulai and Tioman Island (Top: Tulai Island; Middle: Kg. Juara; Bottom: Kg. Nipah). 
clear water around the bay, which are home to many fauna and flora. In Tulai Island, the mangrove area is quite diverse compare to other place in Tioman. The dominant species found are Rhizophora stylosa, Rhizophora mucronata, Rhizophora X lamarckii, Rhizophora apiculata, Bruguiera gymnorrhiza, sonneratia alba, Bruguiera sexangula, and Terminalia catappa. Besides, a new hybrid species, Rhizophora X lamarckii between Rhizophora apiculata and Rhizophora stylosa has been found dominated in Tulai Island.

At the mean time only mangrove area in Mangrove bay, Tulai Island was considered as the focal destination for tourists, mostly for diving, snorkeling, and eco-cruising. However, other mangrove areas in Tioman Island were also potential to be promoted as tourist destination area such as Kg. Juara, Kg. Genting, Kg. Paya and Kg. Nipah. Kg. Juara is the only developed village on the eastern side whereas the other 3 villages located on the western part of Tioman Island. The dominant species found throughout observation at four villages are Bruguiera Gymnorrhiza, Ceriops decandra, Heritiera globosa, Nypa fruticans and Xylocarpus Granatum. At these locations, the morphological of mangrove are different with mangrove species is well mixed at certain location. The species such as Lumnitzera rasemosa and Xylocarpus granatum that usually grow at low salinity can be observed at the front of tidal inlet. Hibiscus and Nypa which is associate mangrove also can be found mix with other species of true mangrove along the river.

\section{Strategy Planning}

There are many strategies that could be adopted in order to promote these areas to become an ecotourism destination.

\subsection{Identifying Appropriate Locations for Ecotourism Development}

The strategic ecotourism locations with accessibility in terms of facilities (hotel, resort, diving centre near to area), uniqueness of the biophysical scenery with low impact to environment are quiet important in order to attract tourist.

\subsection{Designing the Facilities, Which Emphasize Blending with the Natural Surrounding}

Installation of basic facilities such as information counter, walking trails, garbage boxes and toilets are considered necessary. Besides, the main information panel and site map should be provided on the mangrove sites to facilitate tourist's access the mangroves areas. Furthermore, the actual site of these facilities and on-site information guides should be strategically located to keep the expected negative impact within the minimum limit of acceptable change and to maintain the biophysical stability of the sites.

\subsection{Construction of Non-Intrusive Ecotourism Facilities in a Natural Setting}

The scientific and long term planning in developing non-intrusive facilities within mangrove forest should be undertaken. For instance, boardwalks constructed for visitor to access the mangrove area must not interfere the root system and stand. The concrete and metals used in building boardwalks can react with water and soil causing changes in $\mathrm{pH}$. Consequently, this will affect the zonation of flora and wildlife species at mangrove forest [13].

\subsection{Identifying Proper Ecotourism Activities That Do Not Harm in the Environment}

The activities such as kayaking, snorkeling, scuba diving, nature trail, research and education tour and tracking, photography, bird watching, and mangrove tree plantation or adoption attract more tourists to the mangrove forest while promoting the conservation of this natural setting.

\section{Conclusion}

Mangroves are richly diverse in Tioman and Tulai Island. A total of 23 mangrove species occupy small portion of the island (59.895 hectares). A new hybrid species, Rhizophora X lamarckii was found dominated in Tulai Island. This hybrid species is between Rhizophora stylosa and Rhizophora apiculata. Based on the study, there are many areas covered by mangrove areas such as Kg. Paya, Genting, Juara and Nipah. Mangroves in other areas such as Air Batang, Tekek and Salang are declined due to coastal development. Mangroves produce a lot of 
valuable ecological and socioeconomic benefits to human. However, people are more focused on the socioeconomic value as the ecological value of mangroves is intrinsic and not immediately identifiable. Therefore, mangrove is often considered as wasteland rather than highly prized ecosystem. In order to capture the interest and understanding of people, it is important to provide income based on the ecological value of mangroves. One way in which this can be done is through the development of ecotourism in the mangroves. With thorough planning and careful consideration of the economic, environmental and cultural aspects of such developments, ecotourism can contribute to conservation, education, resource protection and the involvement of local people (work opportunity). Since mangroves provide various important functions in nature, it hopes that the mangrove ecotourism activity will influence the people and community's attitudes to the environment, conservation and sustainable development in a very positive way.

\section{References}

[1] Alongi, D.M. (2009) The Energetic of Mangrove Forest. Springer, New York, 1-125.

[2] Farnsworth, E.J. and Ellison, A.M. (1997) The Global Conservation Status of Mangroves. Ambio, 26, 328-334.

[3] FAO (2007) The World's Mangroves 1980-2005. FAO, Rome, 21-27.

[4] Shahbudin, S. Zuhairi, A. and Kamaruzzaman, Y. (2012) Impact of Coastal Development on Mangrove Cover in Kilim River, Langkawi Island, Malaysia. Journal of Forestry Research, 23, 185-190.

[5] MET (2010) Northeast Monsoon Report. Malaysian Meteorological Department.

[6] MET (2011) Southwest Monsoon Report. Malaysian Meteorological Department.

[7] Green, E.P., Clark, C.D., Mumby, P.J., Edwards, A.J. and Ellis, A.C. (1998) Remote Sensing Techniques for Mangrove Mapping. International Journal of Remote Sensing, 19, 935-956.

[8] (1999) ERDAS Field Guide. ERDAS® Inc., Georgia.

[9] NASA (2009) Field Guide to Image Processing. http://rst.gsfc.nasa.gov/Front/tofc.html

[10] Vaiphasa, C., Ongsomwang, S., Vaiphasa, T. and Skidmore, A.K. (2005) Tropical Mangroves Species Discrimination Using Hyperspectral Data: A Laboratory Study. Estuarine, Coastal and Shelf Science, 65, 371-379. http://dx.doi.org/10.1016/j.ecss.2005.06.014

[11] Aston, E.C. and Macintosh, D.J. (2002) Preliminary Assessment of the Plant Diversity and Community Ecology of the Sematan Mangrove Forest, Sarawak, Malaysia. Forest Ecology and Management, 166, 111-129. http://dx.doi.org/10.1016/S0378-1127(01)00673-9

[12] Lokman, M. (2004) Exploring the Interface: The Enigmatic Mangroves. Universiti Terengganu Malaysia, Terengganu.

[13] Ali, M. and Musa, M.F. (2011) Environmental Impacts of Ecotourism on Mangrove: Case Study of Kuala Selangor Nature Park. In: Social Capital and Development Trend in Rural Area, Marginal Areas Research Group, Japan, 101-111. 